\title{
THE EFFECT OF DIET SUPPLEMENTED WITH DANDELION'S (TARAXACUM OFFICINALE) EXTRACT ON THE PRODUCTIVE AND BLOOD PARAMETERS OF COMMON CARP (CYPRINUS CARPIO L.), CULTIVATED IN THE RECIRCULATION SYSTEM
}

\author{
Ivaylo Sirakov, Katya Velichkova, Stefka Stoyanova, \\ Georgi Zhelyazkov, Yordan Staykov
Department of Biology and Aquaculture, Faculty of Agriculture, Trakia University, Students campus, 6014 Stara Zagora, Bulgaria

Received 28 October 2018; Received in revised form 9 April 2019; Accepted 14 May 2019

\begin{abstract}
The aim of the current study was to test the effect of a diet supplemented with dandelion's (Taraxacum officinale) extract on the productive traits and blood parameters in common carp (Cyprinus carpio L.) cultivated in an recirculation aquaculture system. The carps were cultivated at a stocking density of $7.2 \mathrm{~kg} / \mathrm{m}^{3}$ in recirculation aquaculture system. The fish were split into the following two experimental groups: DF (the fish were fed with feed supplemented with dandelion's extract) and CF (the fish were fed with feed without supplementation). Common carp fed with a diet added with dandelion's extract at a quantity of $0.8 \%$ from daily feed ratio, did not affect the hydrochemical parameters $(\mathrm{pH}$, dissolved oxygen, and electrical conductivity). The carps fed with feed supplemented with dandelion's extract did not show better productive traits compared with these found for carp from the control variant. The carp from experimental groups had a higher survival rate, final weight, average individual weight gain and specific growth rate (SGR), respectively with $13.2 \%, 3.94 \%, 31.5 \%$ and $31.3 \%$, compared with the average values of these parameters measured in individuals fed with the control feed, but the differences were not statistically significant $(\mathrm{P} \geq 0.05)$. Supplementation of feed with dandelion's extract significantly decreased the plasma cholesterol $(4.76 \%)$ and triglyceride $(61.2 \%)$ content, promoting hypolipidemic status in fish $(\mathrm{P} \leq 0.05)$.
\end{abstract}

Key words: Dandelion's extract, common carp, growth, blood parameters, RAS

\section{INTRODUCTION}

The recirculation aquaculture system (RAS) is a sustainable technology which is able to decrease the impact of aquaculture on the environment and to ensure environmentally friendly aqua production. These systems possess different advantages: they reduce water usage, improve waste management and nutrient recycling (1). Together with the advantages, however one of the most important disadvantages is

Corresponding author: Assoc. Prof. Ivaylo Sirakov, $\mathrm{PhD}$ E-mail address: ivailo_sir@abv.bg

Present address: Department of Biology and Aquaculture, Faculty of Agriculture, Trakia University, Students campus,

6014 Stara Zagora, Bulgaria

Phone: +359896669829

Copyright: (C) 2019 Sirakov I. This is an open-access article published under the terms of the Creative Commons Attribution License which permits unrestricted use, distribution, and reproduction in any medium, provided the original author and source are credited.

Competing Interests: The authors have declared that no competing interests exist.

Available Online First: 9 June 2019

Published on: 15 October 2019

https://doi.org/10.2478/macvetrev-2019-0017 the negative effect of high stocking density on fish health and growth $(2,3)$.

Antibiotic substances could promote growth and improve fish health, thus solving in this way the problems described in RAS. Antibiotics have been in wide use in fish farms ever since (4). Unfortunately, it was found that frequent use of antibiotics led to resistance in pathogen microorganisms, suppression of aquatic animal's immune system and pollution of the environment (5). One sustainable solution of the mentioned problems in RAS is the usage of extracts from different plants. It was reported that they could be used as an anti-stress, growth promoting, appetite-stimulating substances. It was found that they have hepatoprotective, immunostimulating effect and anti-pathogen properties in fish (6). The attractiveness of phytoextracts relies on their local availability and low price. Different plant extracts were tested for their growth promoting effect in aquaculture - Urtica dioica (7), Viscum album (7), 
Cynodon dactylon (8), Allium sativum (9), Satureja khuzestanica (10), Sauropus androgynus (11), Stacys lavandulifolia $(12,13)$. It was found that some of them together with providing improved appetite, digestibility, and availability of nutrients also showed an immunostimulating effect in cultivated fish (6).

The dandelion's extract has been used in Bulgarian traditional medicine for hundreds of years as an appetite promoting substance and herbal medication for improving the condition of the gut, liver, and spleen. It contains various phytochemicals, including oligosaccharides, phenolic acids, polysaccharides, flavonoids, peptides, terpenes, and alkaloids. Most of them result in antibacterial, antioxidant, immune function modulating activities and anti-inflammatory activities in tested organisms (14). The effect of dietary supplementation of dandelion extract on growth and blood parameters was tested in chickens $(15,16)$, pigs $(17,18)$, rabbits (19). The investigations of its influence on growth and hematological parameters in fish are strongly limited $(14,20)$.

The aim of the current study was to test the effect of a diet supplemented with dandelion's (Taraxacum officinale) extract on the productive traits and blood parameters in common carp (Cyprinus carpio L.) cultivated in a recirculation aquaculture system.

\section{MATERIAL AND METHODS}

\section{Fish}

Healthy common carps without visible injuries were chosen and transported from Fish farm Tundja 73, situated near at Nikolaevo town, to the Experimental aquaculture base situated at the Trakia University, Stara Zagora. The fish were split into the following experimental groups:

- Control groups, CF - carps were fed with feed without supplementation

- Experimental groups, DF - carps were fed with feed supplemented with dandelion's extract

The average initial weight of fish from the two groups was:

- Experimental group, DF - 915.06 $\pm 139.8 \mathrm{~g}$

- Control group, CF $-908.5 \pm 171.2 \mathrm{~g}$

The experiment was carried out in two replications (16 specimens). The stocking density of fish was $7.2 \mathrm{~kg} / \mathrm{m}^{3}$. The continuation of the trial was 45 days.

Animal management was approved by the ethics committee of Trakia University (acceptance of projects 3AF/18 and 8AF/18 ).
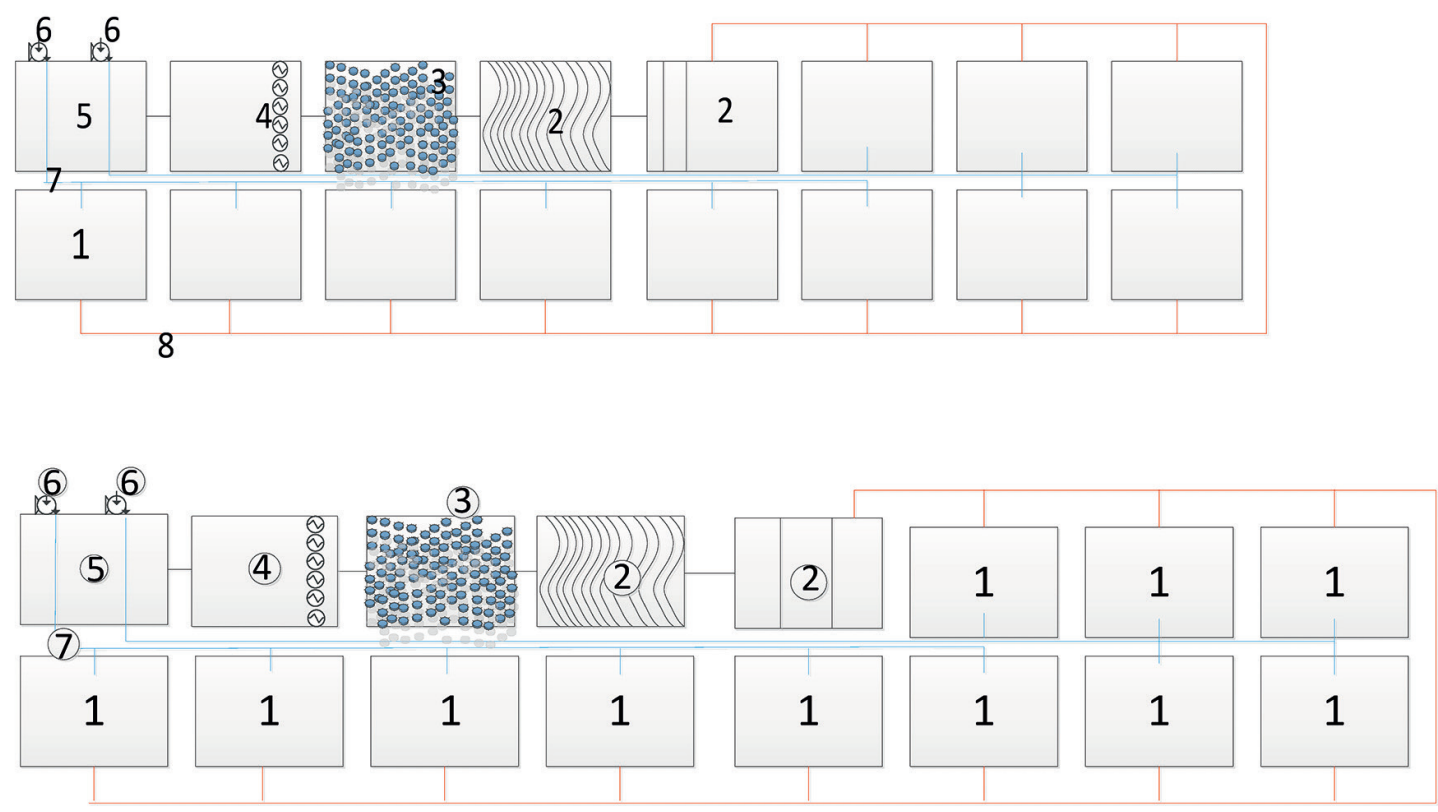

Figure 1. Recirculation aquaculture system: 1- fish tanks;. 2- mechanical filters; 3- moving bed biofilter; 4- heating elements; 5-pump tank; 6-pumps; 7- inlet water; 8- outlet water 
Recirculation aquaculture system (RAS)

The recirculation system consists of fish tanks, two settling tanks as mechanical filters, moving bed biofilter, water heating and pump sections (Fig. 1). The useful volume of each fish tank was $0.8 \mathrm{~m}^{3}$. The flow rate in RAS was maintained at $1331 / \mathrm{min}$. The bottoms of fish tanks, as well as the bottoms of filter's sections, were cleaned by siphoning every day. The volume of fresh water which was added daily for compensation of losses from the cleaning process and from evaporation was $20 \%$ of the total volume of RAS. The heating elements were not used during the current trial because the water temperature was optimal for the raised carps.

\section{Fish feed}

The experimental carps were fed with a commercial pelleted feed, produced by „Top mix“ with the size of pellets $6 \mathrm{~mm}$. Its content could be seen in Table 1. The dandelion's extract (produced by Nature's way) was added to the pellets at a concentration of $0.8 \%$ of the daily feed rate. The sunflower oil at a quantity of $5 \mathrm{ml}$ was also added to every $100 \mathrm{~g}$ of experimental feed and the components were very well mixed. The same amount of sunflower oil was added to the control feed (to ensure the same feed energy) and the pellets and oil were mixed. Afterward, both tested feeds were left for 12 hours at an air temperature of $20^{\circ} \mathrm{C}$ and were used for the feeding of carps. The daily feed rate was maintained at $1.8 \%$ of the total fish biomass. The feed was supplied manually three times a day (8.00 am, $12.00 \mathrm{am}, 16.30 \mathrm{pm}$ ).

Table 1. Nutritional content of commercial feed used in the trial based on "Top mix" manufacture

\begin{tabular}{lll}
\hline Ingredients & Unit & Content \\
Crude protein & $\%$ & 25 \\
Fibers & $\%$ & 6.0 \\
Fat & $\%$ & 3.10 \\
Phosphorus & $\%$ & 1.04 \\
Vit.A & $\mathrm{IU} / \mathrm{kg}$ & 4800 \\
Vit.D & $\mathrm{IU} / \mathrm{kg}$ & 900 \\
Total energy & $\mathrm{MJ} / \mathrm{kg}$ & 11.10 \\
\hline
\end{tabular}

\section{Investigated parameters: Hydrochemical} analysis

The temperature $\left({ }^{\circ} \mathrm{C}\right), \mathrm{pH}$, dissolved oxygen $(\mathrm{mg} / \mathrm{l})$ and electrical conductivity $(\mu \mathrm{S} / \mathrm{cm})$ were measured daily with a portable meter HQ30D (Hach Lange, Germany country and company name, both), connected with a probe appropriate for each parameter. The difference in the value of average water's temperature during the trial between experimental and control tanks was $0.1^{\circ} \mathrm{C}$ and it was not statistically proven ( $\mathrm{P} \geq 0.05$ ) (Table. 2$)$. The measured average value of oxygen in tanks from the DF variant was $6.62 \mathrm{mg} / \mathrm{l}$ (Table. 2) and it was $6.3 \%$ higher than the average value measured for the control group $\mathrm{CF}$, but the difference was not statistically significant $(\mathrm{P} \geq 0.05)$. The differences between the average values of $\mathrm{pH}$ and conductivity between both tested variants DF and CF were minimal and not statistically proven (Table. 2$)(\mathrm{P} \geq 0.05)$.

Table 2. Average value of hydrochemical parameters during the trial

\begin{tabular}{lcc}
\hline Hydrochemical parameters & DF & CF \\
\hline Temperature $\left({ }^{\circ} \mathbf{C}\right)$ & $24.00 \pm 1.48$ & $24.1 \pm 0,5$ \\
Dissolved oxygen $(\mathbf{m g} / \mathbf{l})$ & $6.52 \pm 0.22$ & $6.2 \pm 0,4$ \\
pH & $7.88 \pm 0.21$ & $7.9 \pm 0,7$ \\
Electrical conductivity $(\boldsymbol{\mu S} / \mathbf{c m})$ & $678 \pm 15.00$ & $679 \pm 20$ \\
\hline
\end{tabular}

\section{Technological parameters}

The mortality cases in experimental tanks were recorded during the trial and survival (\%) was calculated using the following formulae:

$$
\text { Survival }(\%)=\frac{\text { final number of fish }}{\text { initial number of fish }} \times 100
$$

The experimental fish were individually weighed at the technical balance with accuracy of $0,01 \mathrm{~g}$ at the start and the end of the trial. On this basis, the average individual weight gain (WG) (g) and specific growth rate (SGR ) (\% / day) were determined by the following equations:

WG =average final weight - average initial weight

$S G R\left(\%\right.$. day $\left.^{-1}\right)=\frac{(\text { Ln final weight }- \text { Ln initial weight })}{\text { number of days }} \times 100$

At the end of trial feed conversion ratio (FCR) was also calculated by the following equation:

$$
F C R=\frac{\text { Feed fed }(g)}{\text { Weight gain of fish }(g)}
$$

\section{Measurement of blood parameters}

The blood was taken directly from the hearts of the examined fish (12 specimens from the experimental and the control group) with 
disposable sterile plastic syringes $(3 \mathrm{ml})$ with a needle. Heparin sodium (1\%) was used as an anticoagulant. Half of the blood was centrifuged at $1006 \mathrm{~g}$ for separating the plasma for determination of biochemical parameters and the remaining blood was used for hematological analysis. Glucose (GLU) (mmol/l), urea (UREA) (mmol/l), creatinine (CREA) $(\mu \mathrm{mol} / \mathrm{l})$, total protein $(\mathrm{TP})(\mathrm{g} / \mathrm{l})$, albumin (ALB) $(\mathrm{g} / \mathrm{l})$, alanine aminotransferase (ALAT) (U/1), aspartate aminotransferase (ASAT) U/1), the content of calcium $(\mathrm{Ca})(\mathrm{mmol} / \mathrm{l})$, phosphorus (P) $(\mathrm{mmol} / \mathrm{l})$, magnesium $(\mathrm{Mg})(\mathrm{mmol} / \mathrm{l})$, as well as triglyceride (TG) $(\mathrm{mmol} / \mathrm{l})$ and cholesterol (mmol/l) in blood plasma, were examined by the colorimetric method with blood analyzer (Mindray SC - 120), (21). The numbers of white blood cells (WBC) (n/l), red blood cells (RBC) (n/l) were determined according to Ranzani-Paiva et al. (22). The content of hemoglobin ( $\mathrm{Hb})(\mathrm{g} / \mathrm{l})$ was measured spectrophotometrically according to
Hayatbakhsh et al. (23). The hematocrit value (\%) was determined according to Ejraei et al. (24).

The blood parameters $\mathrm{MCV}, \mathrm{MCH}$ and $\mathrm{MCHC}$ were calculated with the following equations:

$$
\begin{aligned}
& M C V=\frac{\text { Hematocrit }(\%) \times 10}{R B C \times 10^{12} l} ; \\
& M C H=\frac{\text { Hemoglobin }(g / d L) \times 10}{R B C \times 10^{12} l} ; \\
& M C H C=\frac{\text { Hemoglobin }(g / d L) \times 100}{\text { Hematocrit }(\%)} ;
\end{aligned}
$$

\section{Statistical analysis of data}

The data were analyzed statistically with two methods: ANOVA single factor and independent T-test STATISTICA 6.0 software (StatSoft Inc., 2002) and SPSS version 17 (IBM Inc.).

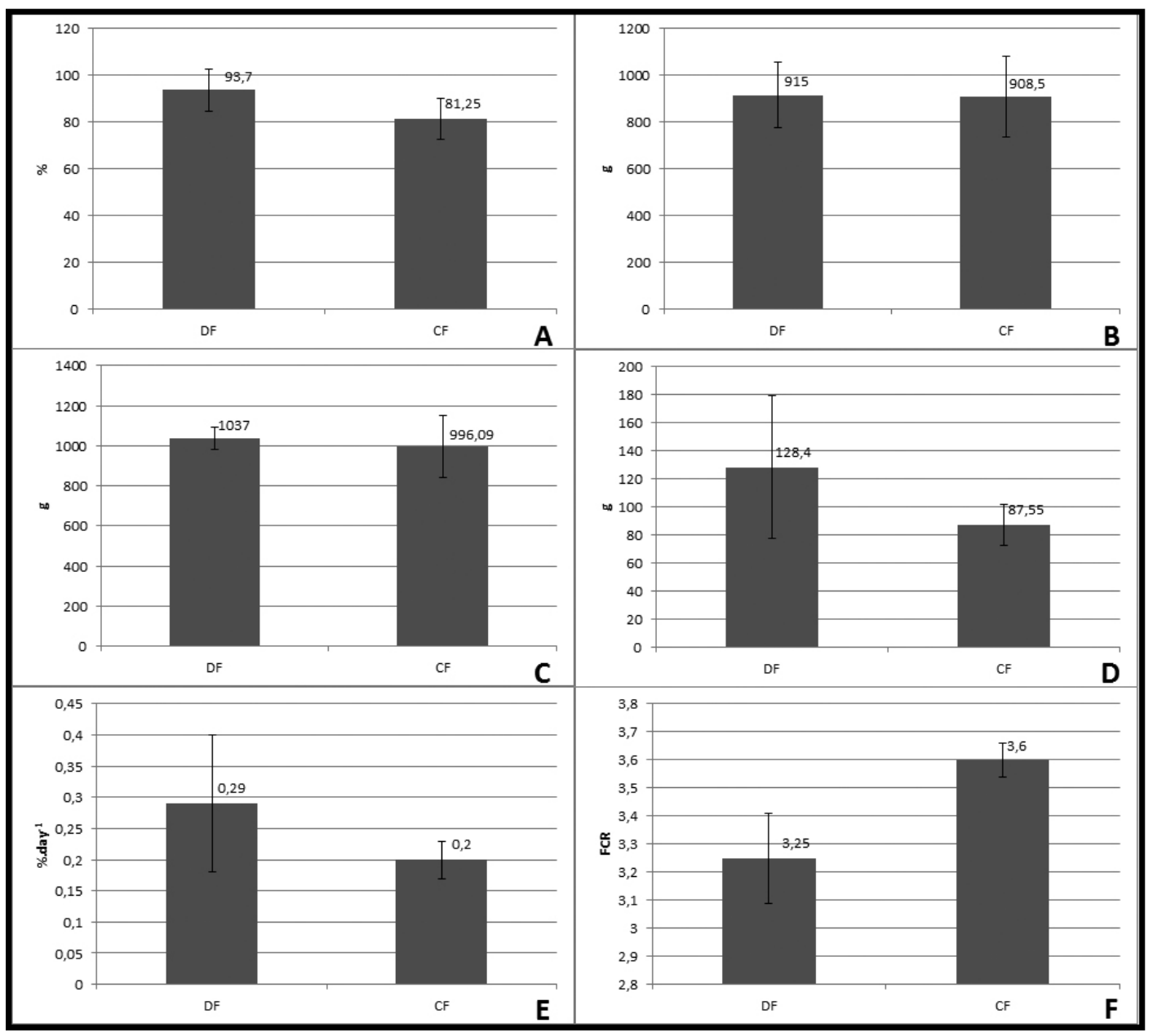

Figure 2. Average values of productive parameters in common carp during the trial: A) survival; B) initial weight; C) final weight; D) average individual weight gain; E) SGR; F) FCR 


\section{RESULTS}

\section{Technological parameters}

The survival rate of carps from the experimental variant DF was by $13.2 \%$ higher than the rate for fish from the CF (Fig. 2), without being statistically proven $(\mathrm{P} \geq 0.05)$.

The statistical differences in fish weights at the beginning of the trial from different experimental variants were not significant $(P \geq 0.05)$. At the end of the experiment, the carp fed with feed supplemented with dandelion's extract showed higher final weight, average individual weight gain and specific growth rate (SGR) respectively with $3.94 \%, 31.5 \%$ and $31.3 \%$ compared with the average values in these parameters found out in carps fed with control feed, but the differences were not statistically significant $(\mathrm{P} \geq 0.05)$.

Better FCR was found in carps from the DF variant and the average value of this parameter was lower by $9.7 \%$ compared with the average value of FCR found for fish fed with feed without supplementation (Fig. 2). Unfortunately, the difference was not statistically significant $(\mathrm{P} \geq 0.05)$

\section{Blood parameters}

At the end of the trial, the biochemical parameters of blood (urea, creatinine, albumin, total protein, $\mathrm{Ca}, \mathrm{Mg}$ ) in carp from the experimental group DF showed higher values for these parameters compared with the ones in fish from the CF variant, but the differences were not statistically proven $(\mathrm{P} \leq 0.05)$ (Table 3). Lower average values in glucose, ALAT, phosphorus, triglyceride and cholesterol were found for the carps fed with supplemented feed, compared with the ones of individuals from the control group (CF), while the differences were statistically significant for triglyceride and cholesterol content $(\mathrm{P} \leq 0.05)$ (Table 3$)$. The values of these parameters in fish plasma from the experimental group (fed with dandelion's extract) were lower respectively by $61.2 \%$ and $4.76 \%$ compared with their values found for carps from the control variant.

Table 3. Average value of hematological and biochemical parameters in carp's blood at the end of trial

\begin{tabular}{|c|c|c|c|}
\hline \multirow[b]{2}{*}{ Blood parameters } & \multicolumn{3}{|c|}{$\bar{x} \pm \mathrm{SD}$} \\
\hline & Unit & DF & $\mathbf{C F}$ \\
\hline GLU & $\mathrm{mmol} / \mathrm{l}$ & $4.8 \pm 0.90$ & $9.54 \pm 3.64$ \\
\hline UREA & $\mathrm{mmol} / \mathrm{l}$ & $1.76 \pm 0.30$ & $1.58 \pm 0.48$ \\
\hline CREA & $\mu \mathrm{mol} / 1$ & $6.0 \pm 2.36$ & $5.6 \pm 2.25$ \\
\hline $\mathbf{T P}$ & $\mathrm{g} / \mathrm{l}$ & $47.6 \pm 10.6$ & $37.3 \pm 7.6$ \\
\hline ALB & $\mathrm{g} / 1$ & $22.7 \pm 4.65$ & $17.8 \pm 3.64$ \\
\hline ASAT & $\mathrm{U} / 1$ & $7.66 \pm 7.17$ & $7.5 \pm 8.50$ \\
\hline ALAT & $\mathrm{U} / 1$ & $19.00 \pm 7.8$ & $23.66 \pm 9.7$ \\
\hline $\mathbf{C a}$ & $\mathrm{mmol} / \mathrm{l}$ & $2.46 \pm 0.32$ & $2.04 \pm 0.44$ \\
\hline $\mathbf{P}$ & $\mathrm{mmol} / \mathrm{l}$ & $2.24 \pm 1.23$ & $2.34 \pm 1.23$ \\
\hline Mg & $\mathrm{mmol} / \mathrm{l}$ & $1.72 \pm 0.21$ & $1.65 \pm 0.20$ \\
\hline TG & $\mathrm{mmol} / \mathrm{l}$ & $0.95 \pm 0.59^{*}$ & $2.45 \pm 1.39$ \\
\hline CHO & $\mathrm{mmol} / \mathrm{l}$ & $2.20 \pm 0.35^{*}$ & $2.31 \pm 0.30$ \\
\hline WBC & $\mathrm{x} 10^{9} 1$ & $135.6 \pm 30.9$ & $164.4 \pm 35.9$ \\
\hline RBC & $\mathrm{x} 10^{12} 1$ & $0.63 \pm 0.09$ & $0.70 \pm 0.18$ \\
\hline HGB & $\mathrm{g} / 1$ & $91.8 \pm 14.3$ & $92.3 \pm 11.5$ \\
\hline HCT & $\%$ & $9.85 \pm 2.11^{*}$ & $12.80 \pm 3.5$ \\
\hline MCV & $\mathrm{x} 10^{15} 1$ & $177.2 \pm 5.67^{*}$ & $152.6 \pm 6.06$ \\
\hline MCH & $\mathrm{x} 10^{12} \mathrm{~g}$ & $1373.49 \pm 354.83$ & $1525.94 \pm 468.55$ \\
\hline МСНC & $\mathrm{g} / \mathrm{dL}$ & $777.72 \pm 216.69^{*}$ & $1000.88 \pm 312.98$ \\
\hline
\end{tabular}

* Asterisk (*) denotes a significant different at $\mathrm{P}<0.05$ 
The hematological parameters (RBC, hemoglobin and hematocrit) showed higher values in the blood of common carp from the CF variant, compared with the ones of fish from the experimental group, but statistically significant was only the difference found with regards to the hematocrit $(\mathrm{P} \leq 0.05)$. The hematocrit in carps from the DF was higher by $23.4 \%$ compared with the quantity found in the blood of individuals from the $\mathrm{CF}$. The number of white blood cell (WBC) in carps fed with feed supplemented with the extract from dandelion were $17.5 \%$ lower compared with the values in this parameter for fish from the control variant, but the difference was not statistically significant (Table 3) $(\mathrm{P} \geq 0.05)$. The highest Mean Corpuscular Volume (MCV) was observed in group DF (177.2 $\pm 5.67 \mathrm{fL})$, while the lowest $\mathrm{MCV}$ value $(152.6 \pm 6.06 \mathrm{fL})$ was observed in group CF. Analysis of the variance of MCV values showed a significant difference $(\mathrm{P}<0.05)$. The mean corpuscular haemoglobin $(\mathrm{MCH})$ in carp from both experimental groups were without statistical differences $(\mathrm{P} \geq 0.05)$ (Table 3). The highest haemoglobin concentration (MCHC) was observed in group CF $(1000.88 \pm 312.98 \mathrm{~g} / \mathrm{dl})$, while the lowest $\mathrm{MCHC}$ was observed in the group DF $(777.72 \pm 216.69 \mathrm{~g} / \mathrm{dl})$. The statistical analysis of the MCHC values from both groups showed a significant difference $(\mathrm{P}<0.05)$.

\section{DISCUSSION}

\section{Technological parameters}

The plant's extracts have shown to be promoting growth, stimulating appetite, reducing stress, as well as possessing anti-microbial properties in fish. Supplements are highly recommended for the purposes of aquaculture and their administration in fish farms has become routine practice (6). The survival rate in carps, fed with dandelion's extract supplemented diet, was not affected by dandelion supplementation in the current trial compared with the rate found for the fish from the control variant, which could be a result of antibacterial and higher immune activity of the used additive. Different in vitro studies showed that the extract from dandelion possesses antimicrobial activity against microorganisms from the genera Escherichia, Bacillus and Staphylococcus (25, 26). Challenging tests in juvenile golden pompano (Trachinotus ovatus) with Vibrio harveyi, fed with diet supplemented with dandelion's extract, showed better survival compared to fish from the control group.
The supplementation of fish and shrimps' feed with plant extracts, increase their growth (6). In the current trial, the values of growth parameters (final weight, average individual weight gain and SGR) and feed conversion ratio (FCR) in fish from the DF group were higher than those found for the carps from the control group, but the differences were not statistically significant $(\mathrm{P} \geq 0.05)$. These results are in confirmation of results, received from Yun et al. (18), who found that feed for juvenile rockfish (Sebastes schlegelii), supplemented with dandelion additive did not affect their growth and feed efficiency (FE). Converse results were found by Tan et al. (12) in juvenile golden pompano (Trachinotus ovatus), where supplementation with dandelion's extract enhanced the growth performance, feed intake and FE. The authors stated that the dosage of dandelion's extract over $1.0 \mathrm{~g} / \mathrm{kg}$ could result in a toxic effect and stress in fish that leads to a decrease in growth and feed utilization. The possible explanation of the differences in results received from Tan et al. (12) and the current study could be that the common carp is reaching this limit dose at a lower level than the one found for the golden pompano (Trachinotus auratus). Future studies are necessary for the optimal dose of dandelion's additive for carp's feeding to be determined.

\section{Blood parameters}

The blood parameters in carps were affected at a higher degree from the substitution of dandelion's extract, than the growth parameters. The addition of different supplements to the fish diet could strongly affect these parameters, which could be used as an indicator of health status in fish (27). The lower quantity of glucose $(50.3 \%)$ in carps, fed with feed supplemented with dandelion, compared to the value of this parameter in fish from the $\mathrm{CF}$ was not proved statistically. The dandelion extracts possess inhibitory activity on a-glucosidase activity, as well as on the antihyperglycemic activity of diabetic mice (28).

A higher level of plasma TP (21.6\%) is found in fish, fed with feed supplemented with dandelion's extract, compared with the one found in carp fed with feed without supplementation. Unfortunately, this difference was not statistically significant $(\mathrm{P} \geq 0.05)$. Tan et al. (12) found a significantly higher level of plasma TP and alkaline phosphatase in golden pompano when it was fed with the addition of dandelion's extract and associate their high level with stronger innate immunity response. The significantly lower level of $\mathrm{TG}$ and $\mathrm{CHO}(\mathrm{P} \leq 0.05)$ in blood plasma in the current study is in confirmation 
of results received from Tan et al. (12) in golden pompano fed with dandelion supplemented feed, which stated that dandelion's addition in feed possesses a hypolipidemic capacity in fish. Similar results connected with the reduction of triglycerides and cholesterol in the blood of common carp were found when wood betony (Stachys lavandulifolia) were administered in fish feed (13).

White blood cells assure protection of organisms against pathogens and toxic compounds. Increased number of WBC in fish showed an inflammatory process (29). The received results for the number of white blood cells in the current study were contrary to results received from Abasali and Mohamad (30), where different herbal immune stimulant diets were used and which led to enhanced WBC's levels.

The number of red blood cells, hemoglobin and hematocrit indicate the oxygen-carrying capacity of fish (31). The RBC, hemoglobin were not affected by the supplementation of dandelion, but hematocrit in carps from the CF variant was higher compared with its quantity in fish from the experimental group, which could result from the lower quantity of oxygen measured in control tanks during the experiment. The Mean Corpuscular Volume (MCV) and the mean haemoglobin concentration (MCHC) in fish blood were affected from supplementation of carp feed with dandelion's extract. The effect of Taraxacum officinale on blood parameters $\mathrm{MCH}, \mathrm{MCV}, \mathrm{MCHC}$ was not retraced in other studies. The effect of supplementation of different medicinal plants (Aloe vera, Origanum vulgare) in fish feed on these parameters in rainbow trout did not show differences compared with the values in $\mathrm{MCH}, \mathrm{MCV}$ and MCHC found for the fish from the control group $(32,33)$.

The main mechanism of action in dandelion's supplementation in feed is connected with stimulation of the digestive system and its diuretic effect. It was reported that dandelion showcases several beneficial effects on the intestinal mucosa in poultry regarding the architecture of the villi, villus height/ crypt depth ratio, as well as cellular infiltration. Unfortunately, this simulative effect was not found in the current study on common carp and only blood parameters were affected from the dandelion supplementation (34).

\section{CONCLUSION}

In conclusion, the current study found that common carp (Cyprinus carpio) fed with a diet supplemented with dandelion extracts at $0.8 \%$ did not affect hydrochemical parameters ( $\mathrm{pH}$, dissolved oxygen and conductivity). The carps fed with added dandelion's extract showed higher survival rate, final weight, average individual weight gain and specific growth rate (SGR), respectively with $13.2 \%, 3.94 \%, 31.5 \%$ and $31.3 \%$, compared with the average values in these parameters found in fish fed with control feed. The differences in survival and growth parameters of the two tested variants were not statistically significant $(\mathrm{P} \geq 0.05)$. Supplementation of feed with dandelion's extract significantly decreased plasma cholesterol and triglyceride content, thus promoting a hypolipidemic status in fish $(\mathrm{P} \leq 0.05)$.

\section{CONFLICT OF INTEREST STATEMENT}

The authors declared that they have no potential conf lict of interest with respect to the authorship and/or publication of this article

\section{ACKNOWLEDGEMENT}

This study was supported by the project $3 \mathrm{AF} / 18$ and 8AF/18.

\section{REFERENCES}

1. Martins, C.I.M., Eding, E.H., Verdegem, M.C., Heinsbroek, L.T., Schneider, O., Blancheton, J. P., ... and Verreth, J.A.J. (2010). New developments in recirculating aquaculture systems in Europe: A perspective on environmental sustainability. Aquacult Eng. 43(3): 83-93.

https://doi.org/10.1016/j.aquaeng.2010.09.002

2. Sirakov, I., Ivancheva, E. (2008). Influence of stocking density on the growth performance of rainbow trout and brown trout grown in recirculation system. BJAS. 14(2): 150-154.

3. Szczepkowski, M., Szczepkowska, B., Krzywosz, T., Wunderlich, K., Stabiński, R. (2010). Growth rate and reproduction of a brood stock of European whitefish (Coregonus lavaretus L.) from Lake Gaładuś under controlled rearing conditions. Archives of Polish Fisheries 18(1): 3-11. https://doi.org/10.2478/v10086-010-0001-4

4. Reda, R.M., Ibrahim, R.E., Ahmed, E.N.G., El-Bouhy, Z.M. (2013). Effect of oxytetracycline and florfenicol as growth promoters on the health status of cultured Oreochromis niloticus. Egypt J Aquat Res. 39(4): 241-248.

https://doi.org/10.1016/j.ejar.2013.12.001 
5. Zhang, Q., Yu, H., Tong, T., Tong, W., Dong, L., Xu, M., Wang, Z. (2014). Dietary supplementation of Bacillus subtilis and fructooligosaccharide enhance the growth, nonspecific immunity of juvenile ovate pompano, Trachinotus ovatus and its disease resistance against Vibrio vulnificus. Fish Shellfish Immunol. 38, 7-14. https://doi.org/10.1016/j.fsi.2014.02.008 PMid:24614017

6. Reverter, M., Bontemps, N., Lecchini, D., Banaigs, B., Sasal, P. (2014). Use of plant extracts in fish aquaculture as an alternative to chemotherapy: current status and future perspectives. Aquaculture 433, 50-61.

https://doi.org/10.1016/j.aquaculture.2014.05.048

7. Dügenci, S.K., Arda, N., Candan, A. (2003). Some medicinal plants as immunostimulant for fish. J Ethnopharmacol. 88(1): 99-106. https://doi.org/10.1016/S0378-8741(03)00182-X

8. Oskoii, S.B., Kohyani, A.T., Parseh, A., Salati, A.P., Sadeghi, E. (2012). Effects of dietary administration of Echinacea purpurea on growth indices and biochemical and hematological indices in rainbow trout (Oncorhynchus mykiss) fingerlings. Fish Physiol Biochem. 38, 1029-1034.

https://doi.org/10.1007/s10695-011-9587-8 PMid:22198162

9. Jegede, T. (2012). Effect of garlic (Allium sativum) on growth, nutrient utilization, resistance and survival of Tilapia zillii (Gervais 1852) fingerlings. J Agric Sci. 4, 269-274.

https://doi.org/10.5539/jas.v4n2p269

10. Khansari, A., Yavari, V., Alishahi, M., Mousavi, S.M., Ghorbanpoor, M., Bastami, K.D., Azizi, S. (2013). Effects of Oliviera decumbens and Satureja khuzestanica extract on some immunological and haematological parameters of Cyprinus carpio. Comp Clin Path. 22, 339-342.

https://doi.org/10.1007/s00580-012-1412-y

11. Putra, A., Santoso, U., Lee, M.-C., Nan, F.-H. (2013). Effects of dietary katuk leaf extract on growth performance, feeding behavior and water quality of grouper Epinephelus coioides. AIJST. 2, 17-25.

12. Babaheydari, S.B., Heyrati, F. P., Akhlaghi, M., Dorafshan, S. (2014). The dietary wood betony, Stachys lavandulifolia Vahl extract as a growth promoter and immune enhancer in common carp (Cyprinus carpio). IJVR. 15(4): 359.

13. Bahrami Babahydari, S., Dorafshan, S., Paykan Heyrati, F., Mahboobi Soofiani, N., Vahabi M.R. (2014). The physiological changes, growth performance and whole body composition of common carp, Cyprinus carpio fed on diet containing wood betony, Stachys lavandulifolia extract. J Agr Sci Tech. 16, 1565-1574.
14. Tan, X., Sun, Z., Chen, S., Chen, S., Huang, Z., Zhou, C., ... Ye, C. (2017). Effects of dietary dandelion extracts on growth performance, body composition, plasma biochemical parameters, immune responses and disease resistance of juvenile golden pompano Trachinotus ovatus. Fish Shellfish Immunol. 66, 198-206.

https://doi.org/10.1016/j.fsi.2017.05.028

PMid:28499965

15. Park, C.I., Shon, J.C., Kim, Y.J. (2010). Effects of dietary supplementation of mulberry leaves and dandelion extracts on performance and blood characteristics of chickens. Korean J Poult Sci. 37(2): 173-180.

https://doi.org/10.5536/KJPS.2010.37.2.173

16. Qureshi, S., Adil, S., El-Hack, M.A., Alagawany, M., Farag, M.R. (2017). Beneficial uses of dandelion herb (Taraxacum officinale) in poultry nutrition. Worlds Poult Sci J. 73(3): 591-602. https://doi.org/10.1017/S0043933917000459

17. Yan, L., Meng, Q.W., Kim, I.H. (2011). The effects of dietary Houttuynia cordata and Taraxacum officinale extract powder on growth performance, nutrient digestibility, blood characteristics and meat quality in finishing pigs. Livestock Sci. 141(2): 188-193. https://doi.org/10.1016/j.livsci.2011.05.017

18. Yan, L., Zhang, Z.F., Park, J.C., Kim, I.H. (2012). Evaluation of Houttuynia cordata and Taraxacum officinale on growth performance, nutrient digestibility, blood characteristics, and fecal microbial shedding in diet for weaning pigs. AsianAustralas J Anim Sci. 25(10): 1439.

https://doi.org/10.5713/ajas.2012.12215

PMid:25049500 PMCid:PMC4093006

19. Rui, Y., Li, J., Li, X., Zeng, F., Li, S., Zhang, X. (2013). Effects of Taraxacum polysaccharides on growth performance and immune function of growing meat rabbits from weaner to 3 Months of age. Chinese Journal of Animal Nutrition, 25, 27702774. [internet] : http://en.cnki.com.cn/Article_en/ CJFDTotal-DWYX201311035.htm

20. Yun, A., Kim, H.S., Seo, Y., Cho, S.H., Bae, J.Y. (2016). Effects of dietary antioxidant supplementation on the growth, serum chemistry, body composition and challenge test results of juvenile rockfish Sebastes schlegelii. Korean J Fish Aquat Sci. 49(3): 323-329.

https://doi.org/10.5657/KFAS.2016.0323

21. Banaee, M., Sureda, A., Mirvaghefi, A. R., Ahmadi, K. (2011). Effects of diazinon on biochemical parameters of blood in rainbow trout (Oncorhynchus mykiss). Pestic Biochem Physiol. 99(1): 1-6.

https://doi.org/10.1016/j.pestbp.2010.09.001 
22. Ranzani-Paiva, M.J.T., Ishikawa, C.M., Eiras, A.C.D., Silveira, V.R.D. (2004). Effects of an experimental challenge with Mycobacterium marinum on the blood parameters of Nile tilapia, Oreochromis niloticus (Linnaeus, 1757). Braz Arch Biol Technol. 47(6): 945-953.

https://doi.org/10.1590/S1516-89132004000600014

23. Hayatbakhsh, M.R., Khara, H., Movahed, R., Sayadborani, M., Rohi, J.D., Ahmadnezhad, M.,.. Rad, A.S. (2014). Haematological characteristics associated with parasitism in bream, Abramis brama orientalis. J Parasit Dis. 38(4): 383-388. https://doi.org/10.1007/s12639-013-0256-y PMid:25320488 PMCid:PMC4185039

24. Ejraei, F., Ghiasi, M., Khara, H. (2015). Evaluation of hematological and plasma indices in grass carp, Ctenopharyngodon idella, with reference to age, sex, and hormonal treatment. Arch. Pol. Fisheries. 23(3): 163-170. https://doi.org/10.1515/aopf-2015-0019

25. Qian, L., Zhou, Y., Teng, Z., Du, C., Tian, C. (2014). Preparation and antibacterial activity of oligosaccharides derived from dandelion. Int J Biol Macromol. 64, 392-394

https://doi.org/10.1016/j.ijbiomac.2013.12.031 PMid:24368113

26. Wang, H. (2014). Cellulase-assisted extraction and antibacterial activity of polysaccharides from the dandelion Taraxacum officinale. Carbohyd Polymer. 103, 140-142.

https://doi.org/10.1016/j.carbpol.2013.12.029

PMid:24528711

27. Lin, H., Tan, X., Zhou, C., Niu, J., Xia, D., Huang, Z., Wang, J., Wang, Y. (2015). Effect of dietary arginine levels on the growth performance, feed utilization, non-specific immune response and disease resistance of juvenile golden pompano Trachinotus ovatus. Aquaculture 437, 382-389.

https://doi.org/10.1016/j.aquaculture.2014.12.025
28. Song, X.Y., Liu, Q., Wang, Z.H. (2009). Antihyperglycemic activity of herbal Taraxaci polysaccharides. China Pharmacy 20, 2095-2097.

29. Harikrishnan, R., Nisha Rani, M., Balasundaram C. (2003). Hematological and biochemical parameters in common carp, Cyprinus carpio, following herbal treatment for Aeromonas hydrophila infection. Aquaculture 221, 41-50. https://doi.org/10.1016/S0044-8486(03)00023-1

30. Abasali, H., Mohamad, S. (2010). Immune response of common carp (Cyprinus carpio) fed with herbal immunostimulants diets. Agricultural Journal 5(3): $163-172$. https://doi.org/10.3923/aj.2010.163.172

31. Wells, R.M.G., Baldwin, J., Seymour, R.S., Christian, K., Brittain, T. (2005). Red blood cell function and haematology in two tropical freshwater fishes from Australia. Comp Biochem Physiol A Mol Integr Physiol. 141(1): 87-93. https://doi.org/10.1016/j.cbpb.2005.04.005 PMid:15893948

32. Pourmoghim, H., Haghighi, M., Rohani, M. S. (2015). Effect of dietary inclusion of Origanum vulgare extract on non-specific immune responses and hematological parameters of rainbow trout (Oncorhynchus mykiss). Bull Env Pharmacol Life Sci. 4, 33-39.

33. Haghighi, M., Sharif Rohani, M., Samadi, M., Tavoli, M., Eslami, M., Yusefi, R. (2014). Study of effects Aloe vera extract supplemented feed on hematological and immunological indices of rainbow trout (Oncorhynchus mykiss). Int $\mathrm{J}$ Adv Biol Biomed Res. 2(6): 2143-2154.

34. Qureshi, S., Adil, S., El-Hack, M. A., Alagawany, M., Farag, M. R. (2017). Beneficial uses of dandelion herb (Taraxacum officinale) in poultry nutrition. Worlds Poult Sci J. 73(3): 591-602. https://doi.org/10.1017/S0043933917000459 